\title{
Presence of eggs of Toxocara spp. and hookworms in a student environment in Rio Grande do Sul, Brazil
}

\author{
Presença de ovos de Toxocara spp. e ancilostomatídeos em ambiente estudantil do Rio Grande do Sul, Brasil \\ Tiago Gallina ${ }^{1 *}$; Maria Antonieta Machado Pereira da Silva ${ }^{1}$; Luciana Laitano Dias de Castro ${ }^{1}$; \\ Emília Welter Wendt ${ }^{1}$; Marcos Marreiro Villela ${ }^{1}$; Maria Elisabeth Aires Berne ${ }^{1}$
}

${ }^{1}$ Departamento de Microbiologia e Parasitologia, Instituto de Biologia, Universidade Federal de Pelotas - UFPel

Received August 24, 2010

Accepted November 5, 2010

\begin{abstract}
Environmental contamination by parasite forms was studied on a university campus in the municipality of Pelotas, Rio Grande do Sul. Soil samples were analyzed using the modified Caldwell \& Caldwell technique to identify parasite forms. Nematode eggs were detected in $62 \%$ of the samples. Among the parasites detected, eggs of Toxocara spp. and Ancylostomatidae were the most prevalent parasites in the studied area throughout the study period. The results demonstrated that there is significant environmental contamination, thereby representing a risk of zoonotic infection for humans frequenting the study area.
\end{abstract}

Keywords: Visceral larva migrans, environmental contamination, helminths.

\section{Resumo}

A contaminação ambiental por formas parasitárias foi estudada na área do campus universitário no município de Pelotas, Rio Grande do Sul. Amostras de solo foram analisadas para identificação de formas parasitárias e a presença de ovos de nematóides foi verificada em $62 \%$ das amostras. Entre os parasitos observados destacam-se a presença de ovos de Toxocara spp. e de ancilostomatídeos em todo período estudado. Os resultados demonstram que há contaminação ambiental significativa, o que representa risco de infecção zoonótica aos humanos que frequentam a região estudada.

Palavras-chave: Larva migrans visceral, contaminação ambiental, helmintos.

Helminthoses are considered to be health hazards for both humans and animals, since the hosts may often become debilitated and present severe consequences. However, such diseases are generally neglected, even in developing countries like Brazil (CHIEFFI; FERREIRA, 2008; MASCARINI-SERRA et al., 2010). Another type of parasitism occurs accidently, especially when humans participate by mistake in parasite cycles that affect domestic animals, such as dogs and cats, thus giving rise to what is classified as a parasitic zoonosis. The presence of stray dogs with access to leisure areas increases the risk of human infections, particularly for children, given that dogs play the role of the definitive host for some species of helminths that may produce significant illnesses (SCAINI et al., 2003) such as visceral larva migrans, caused by Toxocara canis or T. cati (SCHANTZ, 1991) and cutaneous larva migrans, caused by Ancylostoma braziliense and A. caninum (NUNES et al., 2000).

\footnotetext{
${ }^{*}$ Corresponding author: Tiago Gallina

Departamento de Microbiologia e Parasitologia, Instituto de Biologia, Universidade Federal de Pelotas - UFPel, Campus Capão do Leão s/n, CP 354, CEP 96001-970, Capão do Leão - RS, Brazil;

e-mail: tiagogallina@gmail.com
}

Investigations on soil contamination by parasites in public places constitute an important part of public health studies because of the possibility of zoonosis transmission (SILVA et al., 2009). Thus, the aim of the present study was to investigate occurrences of parasite forms in soil samples collected from a student environment in the South of the State of Rio Grande do Sul.

This study was conducted during the four seasons of the year 2009, in leisure areas on the campus of the Federal University of Pelotas (UFPel, Capão do Leão, Rio Grande do Sul), in an area where a municipal elementary school is also located. Around 12,000 people pass through these areas every day, and most of them are students.

Ten of the places most frequented by students during their leisure time were chosen for carrying out the analyses. Four field excursions were made to collect soil samples, one in each season of the year. On each occasion, five soil samples weighing $600 \mathrm{~g}$ each were collected from the perimeters of these preestablished sites. Thus, over the course of the year, 20 samples were taken from each of the 10 sites, totaling 200 samples, i.e. 50 samples per season of the year. Each of the samples was analyzed in quintuplicate. The material was packed in plastic bags, properly identified, and kept 
Table 1. Frequency of soil samples positive for parasite eggs, diagnosed in 2009, in a student environment in the Southern region of the State of Rio Grande do Sul.

\begin{tabular}{|c|c|c|c|c|c|c|c|c|c|c|}
\hline \multirow{2}{*}{$\begin{array}{l}\begin{array}{l}\text { No. of positive samples / } \\
\text { Season of the year }\end{array} \\
\text { Toxocara spp. }\end{array}$} & \multicolumn{2}{|c|}{ Summer } & \multicolumn{2}{|c|}{ Autumn } & \multicolumn{2}{|c|}{ Winter } & \multicolumn{2}{|c|}{ Spring } & \multicolumn{2}{|c|}{ Total } \\
\hline & $24(50)$ & $48 \%$ & $17(50)$ & $34 \%$ & $17(50)$ & $34 \%$ & $34(50)$ & $68 \%$ & $92(200)$ & $46 \%$ \\
\hline Hookworms & $20(50)$ & $40 \%$ & $14(50)$ & $28 \%$ & $18(50)$ & $36 \%$ & $24(50)$ & $48 \%$ & $76(200)$ & $38 \%$ \\
\hline Negative samples & $19(50)$ & $38 \%$ & $23(50)$ & $46 \%$ & $26(50)$ & $52 \%$ & $8(50)$ & $16 \%$ & $76(200)$ & $38 \%$ \\
\hline
\end{tabular}

under refrigeration at the parasitology laboratory of the Institute of Biology at UFPel, until it was processed.

To analyze the material, the Caldwell and Caldwell technique as modified by Pessoa and Martins (1988) was used. This consisted of homogenizing each six-gram soil sample in $10 \mathrm{~mL}$ of $4 \%$ sodium hypochlorite, diluted to $30 \%$, followed by filtration through gauze. The material was centrifuged at $700 \mathrm{~g}$ for 2 minutes; the supernatant was discarded and the remainder was resuspended using $10 \mathrm{~mL}$ of sodium dichromate solution $\left(1.35 \mathrm{mg} \cdot \mathrm{dL}^{-1}\right)$. Next, this sample was centrifuged at $500 \mathrm{~g}$ for 3 minutes, and the final volume was then made up with sodium dichromate until an upper meniscus had formed. A cover slip was placed over this and left for 15 minutes, and the samples were then analyzed.

Out of the 200 samples collected during the four seasons of the year, $124(62 \%)$ contained at least one parasite form Toxocara spp. and hookworms (Table 1) were the parasites most frequently observed. In $25.5 \%$ of the samples, different nematodes with the capacity to infect humans through accidental ingestion or through percutaneous penetration were present. With regard to the different seasons, the greatest incidence of parasites was found in the spring. Nematode eggs presented greater resistance against desiccation: this is an adaptive resistance mechanism to cope with conditions of extreme dehydration, which may explain their presence throughout the year (GAMBOA, 2005; MANDARINO-PEREIRA et al., 2010).

It was observed over the course of the investigation that the population of stray dogs circulating every day in all the areas evaluated was high. The constant presence of eggs of Toxocara spp. and hookworms in the soil, which are parasites that both have zoonotic potential, indicates that the dogs frequenting these areas will present parasite infection and that consequently there is a risk that the human population may become accidentally infected. This finding is concordant with diagnoses made in other localities in the Americas (HOTEZ; WILKINS, 2009; BOWMAN et al., 2010). Human infection due to Toxocara is probably common, and it can be calculated that it must affect millions of individuals in the Americas, although its relevance is underestimated. In addition to environmental contamination, it is emphasized that viable eggs of $T$. canis have also been diagnosed in the fur of the perianal region of dogs in Brazil (AMARAL et al., 2010).

The results from this study demonstrated the existence of high levels of soil contamination due to the feces of domesticated animals in the student environments investigated, with helminths eggs present at all the sites and in all the seasons of the year. This confirmation of the presence of parasites of medical importance in student environments in Southern Brazil serves as a warning, and makes it possible to apply sanitation policies to the risks to which the population is exposed.

\section{References}

AMARAL, H. L. C. et al. Presence of Toxocara canis eggs on the hair of dogs: a risk factor for Visceral Larva Migrans. Veterinary Parasitology, v. 174, n. 1-2, p. 115-118, 2010. PMid:20728996. http://dx.doi. org/10.1016/j.vetpar.2010.07.016

BOWMAN, D. D. et al. Hookworms of dogs and cats as agents of cutaneous larva migrans. Trends in Parasitology, v. 26, n. 4, p. 162-167, 2010 .

CHIEFFI, P. P.; FERREIRA, L. F. Alteraçôes na estrutura epidemiológica da ancilostomose no Estado de São Paulo, Brasil (1900-1987). Revista de Patologia Tropical, v. 37, n. 4, p. 311-321, 2008.

GAMBOA, M. I. Effects of temperature and humidity on the development of eggs of Toxocara canis under laboratory conditions. Journal of Helminthology, v. 79, n. 4, p. 327-331, 2005. PMid:16336716. http://dx.doi.org/10.1079/JOH2005287

HOTEZ, P. J.; WILKINS, P. P. Toxocariasis: America’s Most Common Neglected Infection of Poverty and a Helminthiasis of Global Importance? PLoS Neglected Tropical Diseases, v. 3, n. 3, e400, p.1-4, 2009.

MANDARINO-PEREIRA, A. et al. Prevalence of parasites in soil and dog feces according to diagnostic tests. Veterinary Parasitology, v. 170, n. 1-2, p. 176-181, 2010. PMid:20226595. http://dx.doi.org/10.1016/j. vetpar.2010.02.007

MASCARINI-SERRA, L. M. et al. Reductions in the Prevalence and Incidence of Geohelminth Infections Following a City-wide Sanitation Program in a Brazilian Urban Centre. PLoS Neglected Tropical Diseases, v. 4, n. 2, e588, p. 1-7, 2010.

NUNES, C. M. et al. Ocorrência de larva migrans na areia de áreas de lazer das escolas municipais de ensino infantil, Araçatuba, SP, Brasil. Revista de Saúde Pública, v. 34, n. 6, p. 656-658, 2000. http://dx.doi. org/10.1590/S0034-89102000000600015

PESSOA, S. B.; MARTINS, A. V. Noçóes sobre as principais técnicas usadas em parasitologia. In: PESSOA, S. B.; MARTINS, A. V. Parasitologia Médica. 11. ed. Rio de Janeiro: Guanabara Koogan, 1988. p. 814-854.

SCAINI, C. J. et al. Contaminação ambiental por ovos e larvas de helmintos em fezes de cães na área central do Balneário Cassino, Rio Grande do Sul. Revista da Sociedade Brasileira de Medicina Tropical, v. 36, n. 5, p. 617-619, 2003.

SCHANTZ, P. M. Parasitic zoonosis in perspective. International Journal for Parasitology, v. 21, n. 2, p. 161-170, 1991. http://dx.doi. org/10.1016/0020-7519(91)90006-S

SILVA, P. F. et al. Commom beach sand contamination due to enteropasites on the southern coast of Pernambuco State, Brazil. Revista da Sociedade Brasileira de Medicina Tropical, v. 51, n. 4, p. 217-218, 2009. 